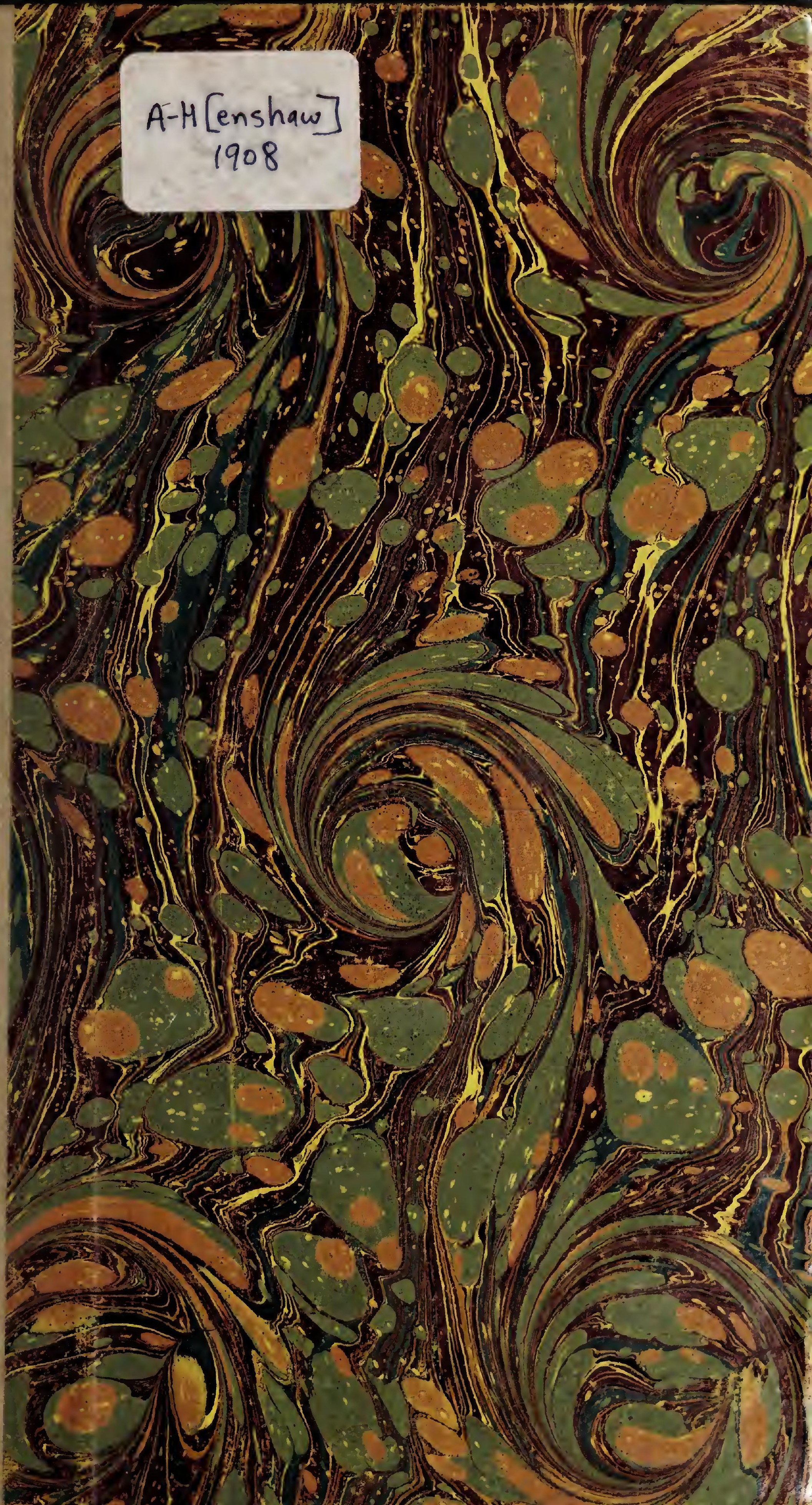




\section{HARVARD UNIVERSITY.}

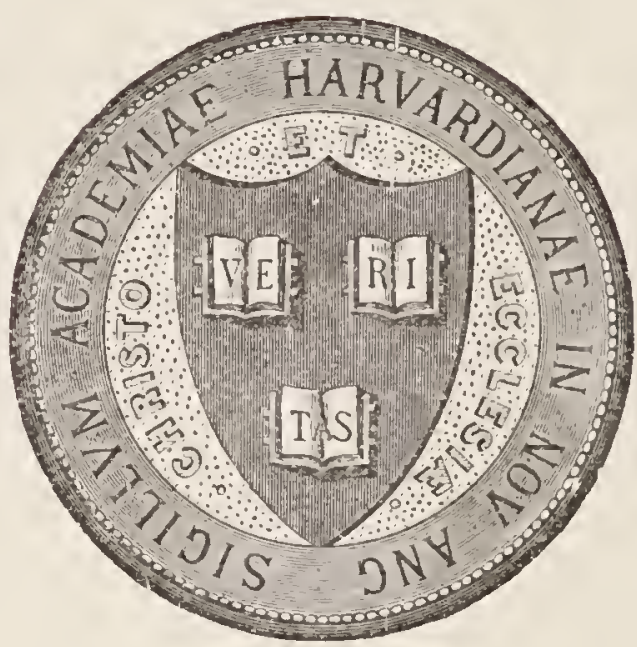

I. I B R A R Y

OF $\mathrm{THE}$

MUSEUM OF COMPARATIVE ZOÖLOGY.

$$
\text { bxchange }
$$

September 21.1908 


\section{DOES IT PAY THE FARMER TO PROTECT BIRDS?}

By

H. W. IIENSHAW,

Administrative Assistant, Biological Survey.

'sm [Reprint from Yearbook of Departiment of Agriculture for 1907.]

$48350-08$

WASHINGTON : GOVERNMENT PRINTING OFFICE: 1908 


\section{CONTENTS.}

Page.

Insectivorous birds and their food habits . . . . . . . . . . . . . . . . . 166

Vegetarian birds and their food habits. . . . . . . . . . . . . . . . . . . 170

Protection of birds from man . . . . . . . . . . . . . . . . . . . . . . . . . . 176

Means of attracting birds to the farm . . . . . . . . . . . . . . . . . . . 177

Means of protecting crops from birds. . . . . . . . . . . . . . . . . . . . 177

Farmers' gain from protecting birds ............................ 178

\section{ILLUSTRATIONS.}

Page.

Plate VI. A useful insect eater-Kentucky warbler................... 168

VII. One of our forest conservators-Red-bellied nuthatch . . . . . . . 168

VIII. A valuable bird in danger of extinction-Field plover......... 172

IX. A typical seed eater-White-throated sparrow . . . . . . . . . . . 172 


\title{
DOES I'T PAY THE FARMER TO PROTECT BIRDS?
}

\author{
By H. W. Hensmaw, \\ Administrative Assistant, Biological Survey.
}

As objects of human care and interest birds occupy a place filled by no other living things, and the various movements to protect and foster them would be fully justified were there no returns other than esthetic. Only the thoughtless and the ignorant still hold that the graceful forms and beautiful plumage of these masterpieces of nature serve their highest purpose when worn on a hat for a brief season, to be then cast aside and forgotten, the plumage dimmed and faded, the beautiful songs quenched forever.

While by no means insensible to the higher value of birds, the farmer who is asked to aid in measures for their protection is entitled to inquire as to the practical purpose they subserve and how far they may be expected to return his outlay of time, trouble, and expense.

Since most birds eat insects and since many eat practically nothing else, it is their insect-eating habits that chiefly invite inquiry, for so active and persistent are birds in the pursuit of insects that they constitute their most important enemies.

When birds are permitted to labor undisturbed they thoroughly police both earth and air. The thrushes, sparrows, larks, and wrens search the surface of the earth for insects and their larvæ or hunt among the leaves and peer under logs and refuse for them. The warblers, vireos, creepers, and nuthatches with their microscopic eyes scan every part of the tree or shrub-trunk, branches, and leavesand few hidden creatures escape them. The woodpeckers, not content with carefully scrutinizing the bark and limbs of trees, dig into decayed and worm-eaten wood and drag forth the burrowing larva, which in their hidden retreats are safe from other enemies. The flycatchers, aided by the warblers, are ever on the alert to snap up insects when flying among trees and branches; while the swallows and nighthawks skim over the pastures and patrol the air high above the tree tops for such of the enemy as have escaped pursuit below. Thus each family plays its part in the never-ending warfare, and the number of insects annually consumed by the combined hosts is simply incalculable. It is well that this is so, for so vast is the number of insects and so great is the quantity of regetation required for their subsistence that the existence of every green thing would bo 
threatened were it not for birds and other agents specially designed to keep them in check.

While birds are not numerous in the sense that insects are, they exist in fair numbers everywhere-or would were it not for the interference of man-and so rapid is the digestion of birds and so perfect their assimilative powers that, to satisfy the appetite of even a small bird, great numbers of insects are needed. Much of this food is hidden and must be searched for; much of it is active and must be vigorously pursued. Hence only by the expenditure of much time and labor do birds procure their daily food. With birds the struggle for existence is peculiarly a struggle for subsistence; shelter is obtained with comparative ease, and if climatic conditions are not to their liking they migrate to other regions.

When by reason of favorable conditions insects have multiplied and become unusually abundant, birds eat much more than at ordinary times; hence the importance of their services during insect invasions. It is not, however, at such periods that their services are most valuable. It is their persistent activity in destroying insects every day, at all seasons, and in every stage of growth-the long, steady pull rather than the spasmodic effort-that tends to prevent insect irruptions and to keep the balance true.

Few birds are wholly beneficial, and there are very few among the harmful ones that have no redeeming traits - that do not, occasionally at least, do good. Most birds most of the time are beneficial; a few birds most of the time are injurious. Certain species may be beneficial in one region and harmful in others, or perform useful services at one season and be injurious at another. Instead, therefore, of being simple, as at first sight they may appear, the relations of birds to man are complex. That the exact nature of the services they render may be better understood, the food habits of certain of the more prominent ones will be briefly reviewer.

\section{INSECTIVOROUS BIRDS AND TIIEIR FOOD IIABITS.}

Hawrs AND Owls.- The strong beaks and sharp talons of the hawks and owls at first sight might be thought designed for more serious work than the destruction of insects, and yet many of the birds of prey make insects an important part of their food. The little sparrow hawk lives largely upon grasshoppers and crickets, and some, even of the larger species, as the Swainson hawk of the Western States, in summer time live almost exclusively upon them. It is very fortunate that so many birds-the hawks among them-are fond of grasshoppers, since these insects multiply so fast and are so very destructive to regetation that but for the rheck on their increase by birds the cost to the farmer of fighting them would be much greater than it is. 
Important as is the work of some of the hawks in destroying noxious insects, this is by no means the chief service the group renders man. Within our boundaries are some 50 species of hawks and 35 species of owls. With the exception of perhaps half a dozen hawks, which subsist mainly upon birds, and the great horned owl, hawks and owls are to be classed as beneficial. It is not to be denied that occasionally the larger species carry off a chicken and kill some game, but such acts are exceptions to the general rule. Mice and other small rodents constitute the chief food of such of the species as are not largely insectivorous, and it is by the destruction of these pests of the farmer that hawks and owls earn protection.

Of late years the acreage under cultivation in the United States has increased rapidly and the value of the crops raised has augmented by leaps and bounds. With increased acreage under cultivation the number of rodents has multiplied correspondingly, because of the abundance of nutritious food and also because their natural foes have been destroyed by man. The services of hawks and owls were never so much needed as now, and these faithful helpers of man are likely to be needed still more in the future; yet thousands of hawks and owls are yearly slaughtered because the part they play in nature's scheme is misunderstood or ignored. Unquestionably individual hawks that have learned the way to the poultry yard should be summarily dealt with, but because occasional individuals of two or three species destroy chickens it is manifestly unfair to take vengeance on the whole tribe. The very name "hen hawk" is a misnomer so far as the birds to which it is chiefly applied are concerned. Moreover, it is made the excuse by the farmer's boy and the sportsman for killing every hawk, large and small, that flies. Thousands of these useful birds are killed annually by the thoughtless for no better reason than that, when sitting motionless, they offer an easy target for the small-bore rifle, or, flying, present a tempting mark for the shotgun. So far has popular misapprehension in regard to these birds gone that again and again States and counties have offered bounties for their heads, thus depleting treasuries, and inviting heavy losses to the farmer through the increased numbers of insects and rodents, which it is the function of these birds to hold in check.

Woodpeciers.-The woodpeckers apparently were expressly designed for the protection of trees, both forest trees and fruit trees. Their chisel-like beaks driven by strong muscles make effective tools with which to dig out of wood the larva of burrowing insects, in which work the long extensible tongues greatly aid. The nature and full extent of the services of woodpeckers in the cause of forest growth and preservation are more clearly recognized as the subject is more carefully studied. 
Of all our woodpeckers the sapsucker is the one exception to the rule. This species eats many insects, but its fondness for the sap of trees, including apple and other orchard trees, with its habit of cutting out sections of the bark to obtain its favorite tipple, renders it a nuisance in some localities. It is one of a number of birds that are harmful and beneficial by turns or according to locality. Little blame attaches to the orchardist who blacklists the sapsucker; but he should familiarize himself with the appearance of his enemy, that he may distinguish him from other kinds, so that his extreme measure of retaliation may not fall upon innocent species which can ill be spared.

Wood warblers.-America is peculiarly fortunate in possessing this beautiful group, in some respects unlike the birds of any other land, and excelled by none in grace of form, sprightly motions, and beauty of plumage. The family is large and numbers of the species included in it visit every part of our domain at some season or other. While some live on or near the ground and share. with the thrushes the task of hunting for ground-frequenting insects, the great majority haunt the trees and shrubbery, and spend their time gleaning an insect harvest from foliage and twigs. Eggs, larvæ, and adult insects alike are welcome, and when flying insects are dislodged from their hiding places the warblers successfully essay the rôle of flycatchers and snap them up on the wing. No insects are too minute to escape their prying eyes, and they are particularly successful in discovering and devouring plant lice, immense numbers of which infest our fruit and shade trees. Finally, it may be said of the warblers that they are truly insectivorous, as they eat rery little vegetable food, and the little they do eat has no special economic value. (See Pl. VI.)

Turushes.- The thrushes and their near allies, the bluebirds, are 1 wo groups of insectivorous birds, all the members of which are fond of fruit. All sorts of wild berries are highly esteemed by them, and no one will deny that they are quite within their rights in appropriating them. Unfortunately, however, the most prominent member of the group-and in some respects the most highly esteemedhas developed an uncontrollable appetite for cherries, strawberries, and other cultivated fruits which often renders him a nuisance to the grower of small fruits. The fruit grower can hardly be expected to accept the confiding habits and the sweet song of the robin as full payment for a crop of cherries upon which depends a considerable part of his own livelihood and that of his family. In connection with the depredations of the robin, it is confidently believed that mulberry, wild cherry, and other fruit-bearing trees of little or no commercial value can be planted near orchards so as to protect the 


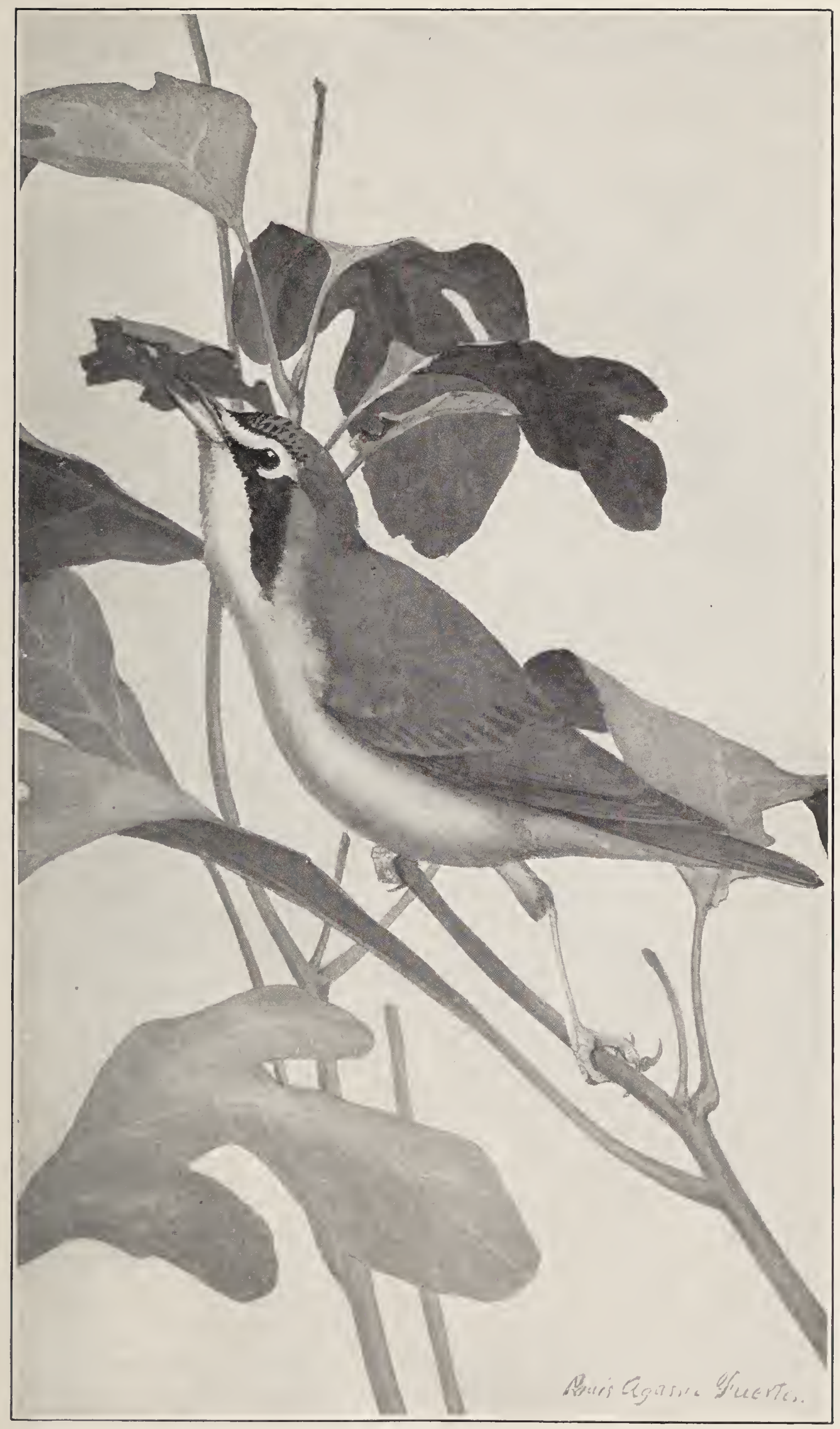

A USEFUL INSECT-EATER-KENTUCKY WARBLER. 



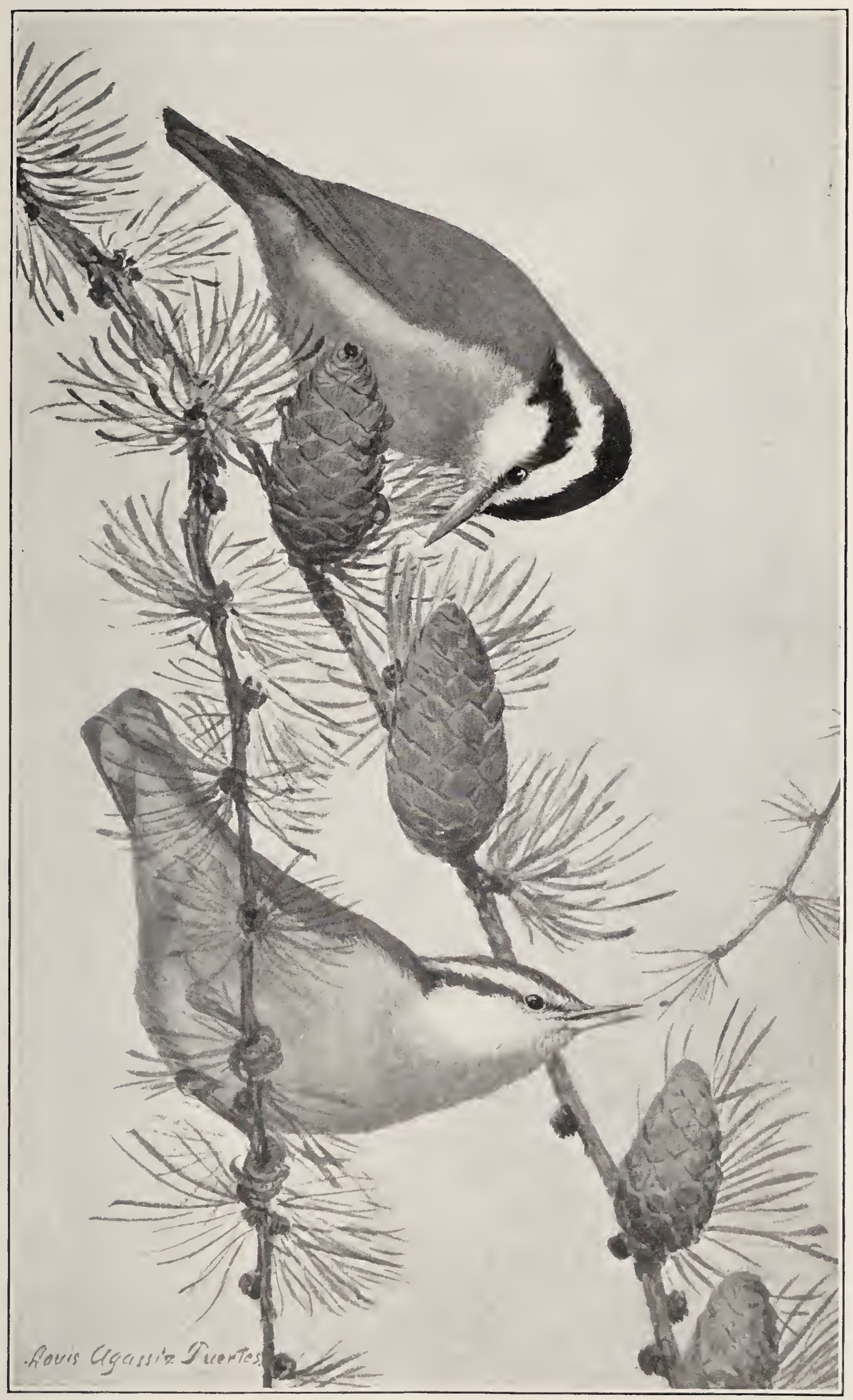

One of OUR Forest CONSERVATORS-RED-BeLlied Nuthatch. 

valuable cherry crop and so save the robin from the orchardist's just resentment. If so, all will be well with the robin; for in respect to his general food habits he is exemplary enough, and destroys many noxious insects, including cutworms and caterpillars. The food habits of the robin have been more carefully studied, perhaps, than those of any other of our birds, and special attention has been paid to the subject by the Biological Survey. That the robin's services as a whole far outweigh the injury he incontestably does to small fruits is the opinion of all investigators, and by the farmer at large he can ill be spared.

The catbird, to some extent, shares the ill name earned by the robin, and for the same reasons; but he is comparatively harmless, being neither so abundant near orchards nor so bold a marauder. Nevertheless, the strawberry patch too often knows him to the sorrow of its owner. He also consumes many insects-cutworms, caterpillars, and grasshoppers among the number.

The smaller members of the thrush family, the wood thrush, hermit thrush, and others, are highly insectivorous, and are to be credited with nothing but good. Moreover their melody raises them to the highest rank among American songsters.

Timmice.-The titmice, like the warblers, are tree frequenters, and the insects they pursue are of the same general character as those eaten by their more nervous and sprightly cousins. Instead of hurrying from tree to tree, and from one branch to another like the warblers, the titmice conduct a comparatively slow and painstaking search and go over their sylvan hunting grounds much more carefully. Another and a far more important fact to their credit is that, like the nuthatches (Pl. VII), they are practically non-migratory, and instead of scurrying off to the sunny Tropics on the first hint of cold weather, as do most of the warblers, they usually winter where they summer. Thus the farmer enjoys the benefit of their services the year round, and hence has twice the incentive to protect them that he has in the case of the migratory species.

Swallows.-The swallows are among the most insectivorous of birds, and it is difficult to overestimate the extent of their services to agriculture. They are flycatchers preeminently, and Nature has been at the utmost pains to qualify them for the delicate task she has set for them-the capture of small insects moving with rapid and uncertain flight through the air. Endowed with the power of swift and enduring flight, swallows cleare the air without apparent effort, turning this way and that, now falling, now rising, following the movements of their prey. The list of species is not lengthy, six only in the States east of the Mississippi and but one more west of that river, but not one of the number could be spared without loss to 
the farmer. Valuable at all times and at all places farored by their presence, swallows have a peculiar value to the southern cotton planter, for they prey upon the cotton boll weevil as it flies over the fields on its errand of destruction. The more that swallows can be induced to nest in the cotton States, and the more they can be increased in the North, so as to add to the number that migrate through the South, the better will it be for the cotton planter, and incidentally for the whole country. Especially important is it that swallows be protected from the assaults of the English sparrow, which covets their nesting sites. Not only do these pests drive away swallows from their nests, but they even throw out their eggs and kill the helpless young.

VEGETARIAN BIRDS AND THEIR FOOD HABITS.

It is not possible strictly to divide small birds by their diet into vegetarian and insectivorous kinds, for while many birds live largely upon vegetable substances-some almost exclusively - there are very few that do not, at least occasionally, eat insects (all of them feed their young upon insects); and, it may be added, there are not many insect-eating birds that do not, at least occasionally, vary their diet by berries or other vegetable substances. Pigeons perhaps are more exclusively vegetarian than other birds, the common turtle dove, for instance, apparently never eating insects except when they happen to be contained in seeds or other vegetable food in the form of eggs or larvæ. For present purposes, however, those birds may be considered vegetarian which live chiefly and most of the year upon vegetable food.

It is among this group naturally that we look for enemies of the farmer, for cultivated grains and fruits are often so much more accessible than the wild varieties that it would be strange indeed if birds had not discovered their good qualities and promptly availed themselves of their opportunities.

Crows.-Crows are as widely as they are unfavorably known for their depredations on corn, especially when it is just sprouting, and their record is further blackened by their appetite for the eggs and nestlings of all small birds and of game birds. Bad as crows are, they yet have redeeming traits, for they devour great numbers of insects, especially grasshoppers and cutworms, and they kill also many meadow mice and other small rodents. The economic status of the crow is, of all birds, one of the most difficult to determine, but the balance is undoubtedly in the bird's favor. The offering of bounties to insure the destruction of crows is mistaken policy, for, as stated above, the crow performs important services to agriculture, and his extermination would be a loss to the country. 
Blacis BIRds.-Blackbirds also, of which there are several species, at times and in certain districts destroy grain. On the other hand, blackbirds consume insects in a wholesale way, and so incline the balance strongly in their favor.

Orroles.-Orioles eat insects to a much greater extent than vegetable food and are noted for their fondness for caterpillars. That the good done by orioles far outweighs the harm can not be doubted, especially since it has been ascertained that in the cotton fields orioles are persistent and successful enemies of the cotton boll weevil, and eagerly search the bolls for them, thus invading the very heart of the enemy's citade?.

Bobolink.-The bobolink, though in summer a deserved favorite at the North and there chiefly insectivorous, in autumn is responsible for damages to the southern rice patches that annually aggregate many thousands of dollars. The bobolink is thus almost in a class by itself, earning deserved protection in summer at the North by reason of its beautiful song and its insect-eating habits, while incurring the severest penalties at the South in the fall for serious depredations on the rice crop. No fair-minded critic can condemn the southern planter who protects his own by means of powder and shot. The extermination of the bobolink is not possible nor is it desirable, at least from the standpoint of those who cherish the bird in its northern home, but a material reduction of its numbers would probably effect a cure and satisfy the rice planters by making the bird practically harmless.

BLUE JAY.- The blue jay is another of our pronounced vegetarians whose fare, taking the whole year round, is largely composed of insects; and were judgment to be pronounced merely as between the good it does by destroying insects and the harm it inflicts by eating corn and fruit, the verdict would be in favor of the bird. A fact, however, recently brought to light seems to indicate that the blue jay is essaying a new rôle. As is well known, the brown-tail moth was introduced into this country a few years ago, and in the New England States has already inflicted serious injury. It will be fortunate for the country at large if the ravages of the insect can be limited to the States already infested. Contrary to the habits of our native moths the eggs of this foreign intruder hatch in the fall, and the young safely winter in their nests in the trees, to issue in the spring and begin their devastations on the opening foliage. Recently it has been learned that hundreds and thousands of these nests are torn open in winter and the young eaten, and the blue jay has actually been seen doing this. The blue jay will earn the title of benefactor indeed should he be able to contribute materially toward a reduction of this pest, which not only threatens destruction alike to village shade trees and country forest, but seriously aftlicts humanity. 
by poisoning the flesh with its barbed hairs, which are scattered broadcast by the wind.

Grouse AND QUAIL.-Grouse and quail are largely vegetarian, though the several species have enviable records as successful hunters of insects. The habit of eating the buds of fruit trees in spring is sometimes cited against our ruffed grouse as a serious fault, but usually trees are not harmed by the process.

The value of all the members of the grouse family, as of waterfowI and waders, for food is great and is constantly increasing as the birds diminish in numbers. Quail have always been favorite objects of pursuit by sportsmen, and by preserving the quail on a large farm, or on a number of adjoining farns, and asking a fair fee from sportsmen for the privilege of shooting, a considerable revenue may be derived, and it is not unlikely that the game on a large tract of, say, several hundred acres may be made to yield a revenue as large as that from a good-sized poultry yard, or even larger. However, perhaps the most valuable service to the farmer rendered by bobwhite is the destruction of the seeds of weeds, although the total number of insects eaten in a year by a covey on the farm is enormous, and it is questionable if the value of game birds to the farmer, especially the quail, as weed and insect destroyers be not greater than their value as a source of revenue from sportsmen or as food. It is pretty safe to assert that, except where grouse and quail are so numerous that a certain percentge of the increase can be spared, the farmer can not afford to sacrifice them to sport or to the market. (See Pl. VIII.)

Sparrow Fanily.-The finch, or sparrow, family is very important to the agriculturist. The group is large, and in North America comprises more than a seventh of all the birds. Most of them are small and plainly colored; some are gregarious, and most are migratory, leaving the United States in winter. Their chief value to the farmer lies in the fact that the marjority of them are indefatigable in their search for seeds of weeds, which indeed constitute a large part of their fare the year round. (See Pl. IX.) Practically all of the food of at least one of them-the tree sparrow-consists of seed. If we estimate that a single tree sparrow eats a quarter of an ounce of weed seed daily - and stomach examinations by Professor Beal show that this is a fair estimate-this species in a State the size of Iowa consumes more than 800 tons of seed annually. And there are many other sparrows whose appetite for weed seed falls little short of that of the tree sparrow.

As every farmer knows, the cost of farming is largely augmented by the expense of fighting weeds, the seeds of many of which, especially of certain noxious kinds, are very numerous and are capable of germinating after being long buried in the soil. As weeds have been estimated annually to damage crop land on the average about a 


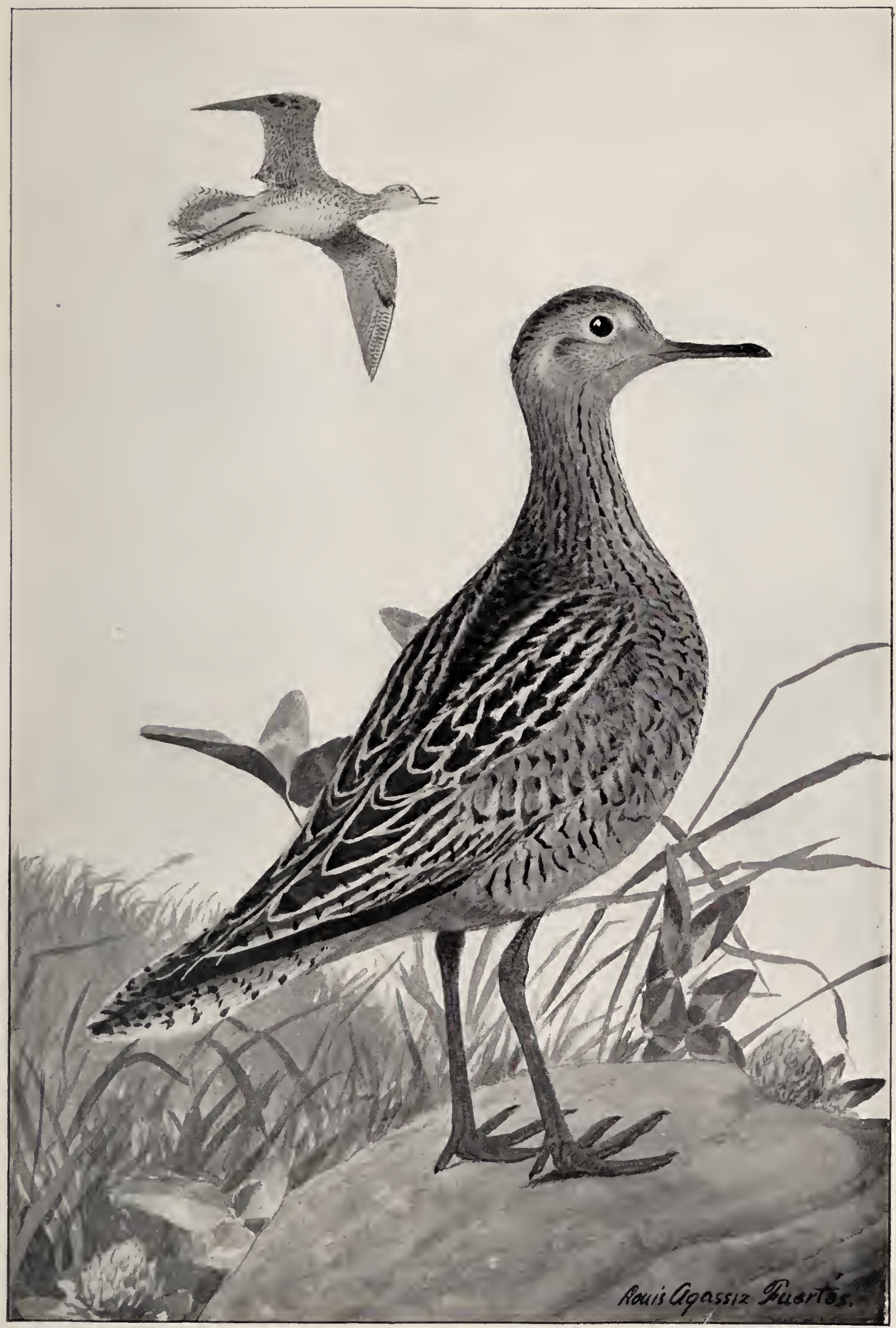

A Valuable Bird in Danger of Extinction-Field Plover. 



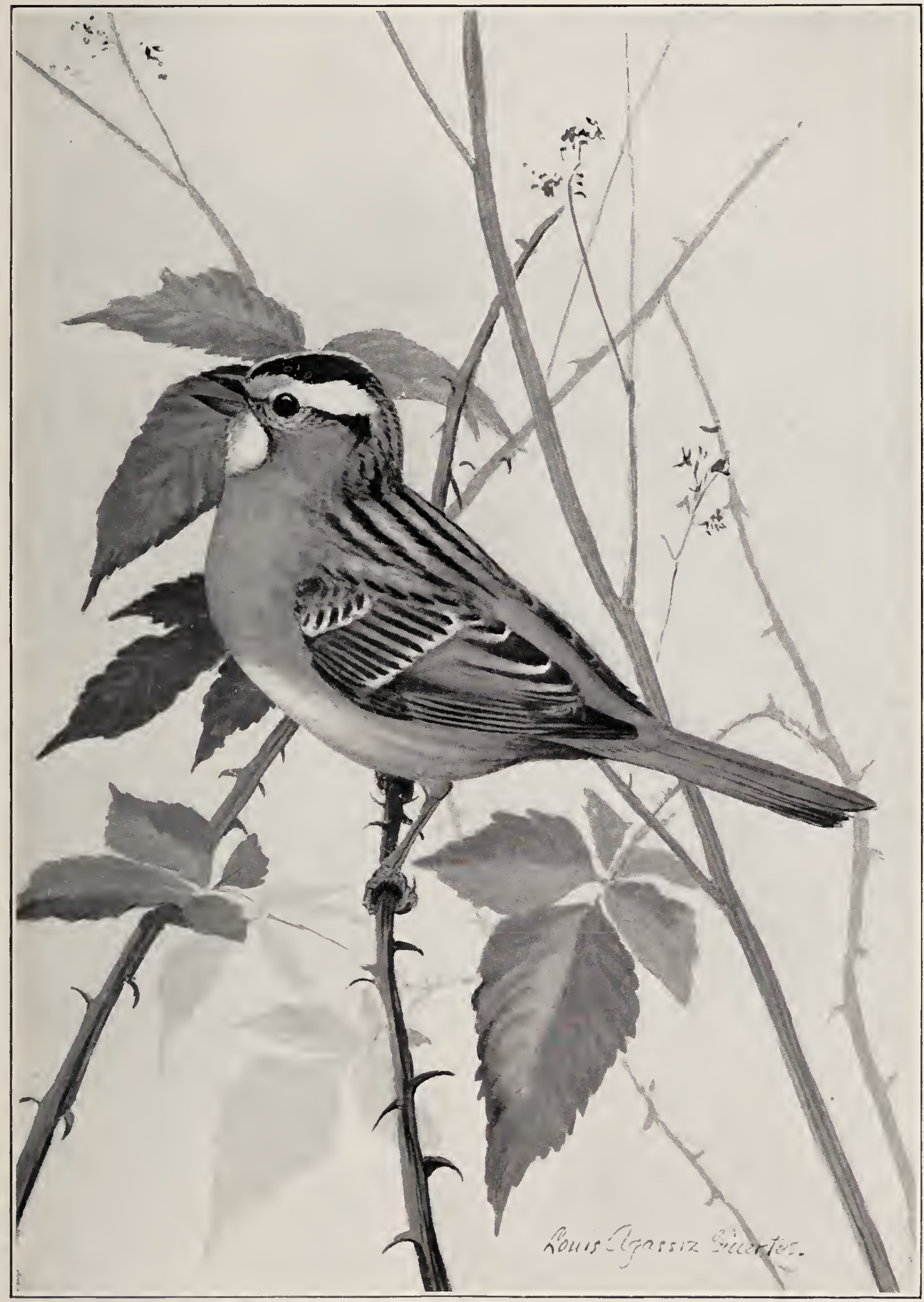

A Typical SeEd-EATER-WHITE-THRoATEd SParrow. 

dollar per acre, and as the lands under crop in the United States in 1899 were $290,000,000$ acres, the good work accomplished by the sparrows is of very great value to the farmer. Without their aid the cost of fighting weeds would be vastly increased, and no doubt in places profitable agriculture would be almost impossible.

Some of the sparrow tribe, as the purple finch and grosbeak, are fond of buds, and in spring may be frequently seen in apple, cherry, peach, and other trees, greedily eating the buds or the stamens of the blossoms. No doubt a certain percentage of fruit is lost through the agency of these birds, but budding by birds in itself, if not carried too far, is by no means objectionable; and neither of the birds mentioned, nor any native bird that shares the habit, is numerous enough (except in California) or sufficiently confirmed in the habit to seriously reduce the fruit crop. Indeed budding by hand to prevent overbearing and to improve the size and quality of fruit is a common practice, and it is probable that, as stated above, in most cases no actual loss of profit follows budding by our native birds. Whether so or not, the purple finch destroys many insects, caterpillars among them, and hence earns favor in the eyes of the farmer; while a still stronger case may be made out for the rose-breasted grosbeak, which is a most determined foe of the Colorado beetle, and probably destroys more of these dreaded insects than does any other bird-possibly than do all other birds combined. The insects eaten by the old birds, however, are but a tithe of the number they feed to their young, for nestlings thrive best and grow faster on a diet composed almost exclusively of insects.

Until the English sparrow was introduced it would have been safe to say that all the sparrows were friends of the farmer and deserved protection at his hands. Unlike our native species, however, this bird has bad habits far outweighing any possible good that it does, even if the most liberal estimate be made of the comparatively small number of insects that it destroys or the weed seed it eats. It is a conspicuous member of the seed-eating group, as its structure abundantly proves, and this well-known fact should have prevented its introduction into the United States to perform the service of an insect eater. By preference the bird is a scavenger of the city streets. Outside the city the bird's fondness for seeds does not stop with weed seed. The smaller grains are liable to attack at all stages of growth, from sowing time to harvest, and the total damage to the grain crop of the country inflicted by this pest at the present time amounts to many thousands of dollars annually.

This sparrow, like some of our native species, is fond of the buds of fruit trees. Where it exists in small numbers the injury it does in this way, like that of our own sparrows, is too small to count much against it; but the bird is rery prolific and in many suburban 
towns its colonies are so large that the resulting damage it inflicts upon fruit trees in spring is very great. It is fond also of all the small fruits, and in some regions the damage to fruit as the result, of its attacks is considerable.

There is yet another field for the exercise of this pest's pernicious activity. Its aggressive and meddlesome disposition and its habit of acting in concert enables it to overpower and drive away many of our native birds, which before its advent were as numerous about dwellings as they were welcome.

The house wren, the bluebird, the phoebe, and certain swallows are the chief sufferers from the aggressive warfare waged by the sparrow. Even that excellent fighter, the purple martin, is unable to long resist the persistent attacks of a united colony of sparrows, since, when unable to overcome the martin in open warfare, the sparrows enter the nests during the absence of the owners, kill the helpless young, and pitch out the eggs. The result is that not only are the abovenamed species and other small birds driven away from the localities they used to inhabit, but their numbers have steadily diminished and must continue to do so because of their inability to find other suitable breeding places. Thus the sparrow has usurped the places about our homes by right belonging to our own birds, and its increase has been at the expense of native American species, with the result that a number of highly important useful species have been replaced over large areas by a single destructive one. Not only should all aid and comfort be withheld from this foreign invader, but a concerted effort should be made to reduce its numbers and to exterminate it wherever and whenever possible.

Cranes and merons.-Some of our birds are neither insect eaters nor vegetable eaters. Some of the hawks and owls, as is well known, live chiefly upon flesh, while the cranes, herons, storks, and kingfishers live largely upon fish, crustaceans, and frogs. By eating small fish which are the fry of valuable kinds or serve as their food, these birds do more or less harm, as the fish breeder, whose ponds are invaded, knows well enough. So also their habit of eating frogs is injurious.

But while thus injurious to some extent in certain localities where their pernicious activity may necessitate reprisals, cranes and herons do good service in the destruction of small rodents, especially meadow mice and pocket gophers. As in other cases the relation of these birds to the community varies according to circumstances, and they are to be dealt with accordingly, bearing in mind, so far as possible, the good to the commmity as a whole and not solely individual interests. 
IMPORTANCE OF BIRDS AS DESTROYERS OF INSECTS.

From the foregoing it will be seen that the benefits the farmer derives from birds far outweigh the occasional damage they do. Notwithstanding this, the public, as a rule, is much more alive to the depredations of birds than to the benefits that accrue from them. Nor is this surprising, since the disastrous effects of a raid on sprouting corn by crows, or upon ripening cherries by robins and cedar birds, are too apparent to be overlooked, and the resulting loss can be estimated in dollars and cents. Not so the benefits. Occasionally, it is true, the effects of a combined attack of birds upon caterpillars, cankerworms, or other insects which are present in unusual numbers or have played havoc with the foliage, are too evident wholly to escape attention; but more often birds work unnoticed, and the good they do is not at once obvious to the busy farmer. There are few visible tokens of the process by which the crop of hay or green feed has been saved from the cutworms by crows, or the potato crop rescued from the Colorado beetle by the grosbeaks. The birds have done their work quietly but none the less effectively. They have saved, or greatly assisted in saving, the farmer's crop, and nobody is the wiser, save the few who make it the business of their lives to study the habits of birds.

The time has long passed when the practical farmer can afford to ignore the relation of birds to agriculture. Larger and larger areas are being devoted to tillage every year, and the amount of capital invested in agricultural pursuits in the United States is constantly increasing. Irrigation, until recently almost unpracticed in the United States, is fast assuming national importance. The whole world is being laid under contribution for new fruits, forage plants, and crops for the benefit of the American farmer, in order that by his superior energy and foresight he may not only feed our own people but create a surplus of American products for consumption in less favored lands.

Along with these new introductions and as a necessary result of international commerce, new pests have been introduced. Here, under a farorable climate and new conditions, they multiply till they inflict great damage. The Hessian fly, San Jose scale, and codling moth are examples in point.

Such pests usually go unnoticed until the damage they do forces them on the attention of a community, when usually they are so numerous and widespread that their extermination is impossible. Once introduced into the country they are here to stay, and the vast sums already spent in efforts to stay the ravages of such pests emphasize the importance of utilizing to the utmost all the allies nature places at our disposal. 
As a means of checking these introduced insect pests, as well as native ones, birds are of vast importance. Yet it must be remembered that, when once the reproductive powers of insects have had full play and an invasion occurs, the farmer can not suddenly augment the number of birds and summon the winged hosts to his aid. Birds reproduce but slowly, and in the natural course of events often suffer immense losses during their migrations, by climatic extremes and through the assaults of birds of prey and predaceous mammals. Hence a marked increase in the number of birds, either as a class or in the case of a given species, must come slowly and as a result of favoring conditions extending over a term of year's. Moreover, as stated above, birds alone are inadequate to cope with sudden insect irruptions. It is their province rather by incessant watchfulness and constant warfare to prevent over-production of insect life rather than to reduce excess, although in the latter regard their aid is important. It is the part of prudence, therefore, to protect useful birds at all times, and so to augment their numbers that they may constantly play their respective parts in the police system ordained by nature and be ready, when emergency arises, to wage active and aggressive warfare against sudden invasions of insect enemies.

PROTECTION OF BIRDS FROM MAN.

Most of. our States have laws which, if fully enforced, would go far to secure adequate protection for birds. The wholesale destruction of our songsters and insectivorous birds for millinery purposes has been largely stopped, although even now in some States the statutes are frequently violated by unprincipled bird hunters for the sake of gain. But laws, while wholesome and necessary, are not so effective for the protection of birds as is an enlightened public sentiment. In a country like our own, where education is general, a knowledge of the part birds play in the economy of nature is more effective for their protection than are any laws, however well administered. Instruction of this kind should be given to every school child in the land, and it is gratifying to note that the importance of this practical side of nature study is fast being recognized by educators. When the value of birds is universally known and they are everywhere cherished as friends, protective laws will be comparatively unimportant.

In this connection brief allusion may be made to a class of immigrants to our shores who are ignorant both of our laws and of the need for enforcing them, and who look upon birds, large and small, only as food. Cheap guns and ammunition in the hands of these newcomers furnish means for the indiscriminate slaughter of birds for the pot, and publie sentiment is either not recognized or is ignored. Nothing but strict laws, rigidly and impartially enforced, can save our birds from these pot hunters. 
MEANS OF ATTRACTING BIRDS TO THE FARM.

There are many ways of attracting birds to the farm and about the farmhouse. A convenient drinking and bathing place near the house is one of the most effective lures for birds known, as well as one of the cheapest. For wrens, swallows, bluebirds, chickadees, and other kinds, which build in cavities of trees, boxes may be put up, care being taken to protect them as far as possible from the aggressive English sparrow. Above all should the farmer pay attention to the cats on his farm. It is only recently that the extent of the depredations of the house cat on wild life, especially on birds, has been recognized. Many who have studied the matter believe that taking the year round cats are responsible for the death of more birds, especially young ones, than all wild animals put together. This may or may not prove to be an exaggeration, but unquestionably cats everywhere, especially on the farm, destroy vast numbers of birds. Even the well-fed and well-housed pet is responsible for many valuable lives, but the greater number are destroyed by strays which mistaken kindness has turned adrift, when not wanted in the house, to live as best they may. An adequate remedy against the bird-catching cat is neither easy to suggest nor to apply, but at least the farmer, who rightfully counts the birds of his farm as his friends, should be expected to destroy the stray cats that infest the country in summer, and, so far as possible, to see to it that the natural instincts of his own house pets are suppressed by ample feeding and reasonable restraint.

\section{MEANS OF PROTECTING CROPS FROM BIRDS.}

There are various devices by means of which the farmer may protect his crops from the attacks of birds, reserving the use of the gun as a last resort when all other methods have failed. Scarecrows, a dead crow hung on a pole, a white cord stretched around a field, the drilling of seed, and the tarring of seed corn are some of the old and approved methods of preventing losses by crows and blackbirds. To be effective, no one of these should be employed exclusively or too long at a time in the same locality, since long contact with man has taught the crow a number of things. Fruit trees when few in numbers may be protected by netting. The planting of wild fruit trees, or those possessed of little commercial value, for the protection of orchards has not received the attention in this country that it deserves.

Even when such protective derices fail the farmer is not driven to the wholesale destruction of birds. For it is being more and more recognized that there is much individuality among birds, and that generally the aggressors in a certain locality are a comparatively few 
individuals. If the lives of a few destructive hawks, crows, or robins are taken, after other means have been tried and failed, it is often enough to protect the poultry yard or the crop.

\section{FARMERS' GAIN FROMI PROTECTING BIRDS.}

The brief survey of the subject possible here only imperfectly sets forth the nature and importance of the service of birds to agriculture. Nevertheless it must appear that to the question "Does it pay the farmer to protect birds?" only one answer is possible. Even from the point of view of an investment for profit the time and expense necessary for their care and protection are richly repaid. There is the added consideration that without the music and companionship of birds the world would be the poorer. Anything that adds to the attractiveness of the farm and increases the interest of farm life is worthy of cultivation, even if no actual return is received in dollars and cents. Happily the farmer who protects birds secures a double return-increased profil from his crops and increased pleasure of living. 
